\title{
Assess the Knowledge Regarding Effect and Pilot Indication of Depression among Rural Women at Selected Village, Tamil Nadu
}

\author{
Kumudhavlli D', Karthi R², M Porselvi ${ }^{3}$, S Girija ${ }^{4}$, M Hemalatha ${ }^{5}$, M Harish ${ }^{6}$,

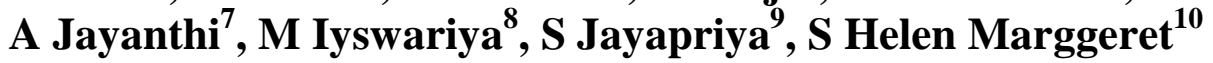 \\ ${ }^{1}$ Assistant Professor, Dept of Community Health Nursing, E.S College of Nursing, Tamilnadu \\ ${ }^{2}$ Professor \& HOD Dept of MSN, E.S College of Nursing, Tamilnadu \\ ${ }^{3}$ Principal, E.S College of Nursing, Tamilnadu \\ ${ }^{4-10}$ Final Year B.Sc., Nursing, E.S College of Nursing, Tamilnadu
}

Corresponding Author: Kumudhavlli D

\begin{abstract}
Aim: To assess the level of knowledge regarding pilot indication and effects of depression among rural women at selected village,".
\end{abstract}

Objectives: (i) To assess the existing level of knowledge regarding effect and pilot indication of depression among rural women. (ii) To find out the association between the level of knowledge regarding effect and pilot indication of depression among rural women with their selected demographic variables.

Methodology: Under the non experimental descriptive design will be adopted for this study. 50 samples were selected by using purposive sampling technique. The effectiveness of knowledge was assessed by the structured knowledge questionnaire.

Result: mean is 10.48 with standard deviation of 3.765 among the 50 samples represent that $6(12 \%)$ of women have adequate knowledge, $20(40 \%)$ were moderate and $24(48 \%)$ belongs to inadequate knowledge.

Conclusion: The study conclude that most of women having inadequate knowledge regarding pilot indication and effects of depression.

Key Words: Pilot indication, Depression, Rural Women.

\section{INTRODUCTION}

Women's health refers to the health of women, which differs from that of men in many unique ways. Women's health is an example of population health, where health is defined by the World Health Organization as "a state of complete physical, mental and social well-being and not merely the absence of disease or infirmity". Often treated as simply women's reproductive health, many groups argue for a broader definition pertaining to the overall health of women, better expressed as "The health of women"

Although women in industrialized countries have narrowed the gender gap in life expectancy and now live longer than men, in many areas of health they experience earlier and more severe disease with poorer outcomes. Gender remains an important social determinant of health, since women's health is influenced not just by their biology but also by conditions such as poverty, employment, and family responsibilities. Women have long been disadvantaged in many respects such as social and economic power which restricts their access to the necessities of life including health care, and the greater the level of disadvantage, such as in developing countries, the greater adverse impact on health. Women's health refers to the branch of medicine that focuses on the treatment and diagnosis of diseases and conditions that affect a woman's physical and emotional well-being. 
Depression (major depressive disorder or clinical depression) is a common but serious mood disorder. It causes severe symptoms that affect how you feel, think, and handle daily activities, such as sleeping, eating, or working

Some forms of depression are slightly different, or they may develop under unique circumstances, such as: Persistent depressive disorder (also called dysthymia); Postpartum depression; Psychotic depression; Seasonal affective disorder; Bipolar disorder .

Depressive disorders account for close to $41.9 \%$ of the disability from neuropsychiatric disorders among women compared to $29.3 \%$ among men.

Leading mental health problems of the older adults are depression, organic brain syndromes and dementias. A majority are women.

\section{WHO's Focus in Women's Mental Health}

Build evidence on the prevalence and causes of mental health problems in women as well as on the mediating and protective factors. Promote the formulation and implementation of health policies that address women's needs and concerns from childhood to old age.

Enhance the competence of primary health care providers to recognize and treat mental health consequences of domestic violence, sexual abuse, and acute and chronic stress in women.

\section{NEED FOR THE STUDY}

Depression is a widespread mental health problem affecting many people. The WHO in 2016 estimated that there are 121 million people worldwide suffering from depression. The life time risk of depression in males is 8 to 12 percent and in females is 20 to 26 percent. Depression occurs twice as frequently in women as in men, and it is currently felt to affect one in four adults to some degree1.

The prevalence of major depression is higher in women than in men; in 2010 its global annual prevalence was $5.5 \%$ and
$3.2 \%$, respectively, representing a 1.7 -fold greater incidence in women. In Canada, the prevalence was $5.0 \%$ in women and $2.9 \%$ in men in 2002 (1.7-fold greater incidence in women) and increased to $5.8 \%$ and $3.6 \%$, respectively, in 2012 (1.6-fold greater incidence in women). The finding of similar female:male prevalence ratios in developed countries and globally suggests that the differential risk may primarily stem from biological sex differences and depend less on race, culture, diet, education and numerous other potentially confounding social and economic factors. There is no clear evidence that the rate of depression is greater in countries where women have markedly lower socioeconomic status than men than in countries where there may be more equal footing.

Depression is more than twice as prevalent in young women than men (ages 14-25 yr), but this ratio decreases with age. Indeed, starting at puberty, young women are at the greatest risk for major depression and mental disorders globally. Importantly, before puberty, girls and boys have similar rates of depression; the rate is perhaps even higher for boys. At ages older than 65 years, both men and women show a decline in depression rates, and the prevalence becomes similar between them. A greater prevalence of depression in women is also reflected in prescriptions for antidepressant medications.

The World Mental Health Survey conducted in 2015, 17 countries found that on average about 1 in 20 people reported having an episode of depression. Depression is a highly prevalent condition, as confirmed by many national and international studies with many possible results. Predicting the outcome at the 8 time of diagnosis can have a stronger clinical impact, since it can help to distinguish people in need of specific treatment from those likely to recover spontaneously. After reviewing various literatures it is revealed that depression is currently felt to affect one in four adults. The researcher feels that depression is a highly prevalent condition which affects 
human life in a variety of ways and the adult's mood can be brought back to the normal state by giving early treatments. If the depression is diagnosed in the earlier stages it would be better. The researcher also felt that early detection of depression helps to undertake specific treatment and thereby reduces the disability in life. As a psychiatric illness, depression exists in all countries across the globe. WHO has identified depression as the number one psychiatric cause of disability in the world and projected that it would rank second in the world as a cause of disability by 2020 .

A study was conducted in South India regarding social origins of depression in women. Over the course of a lifetime, depression occurs in approximately $20 \%$ of women compared with $10 \%$ of men. Although the exact reason for this difference is not known, the higher prevalence of depression in women is most likely due to a combination of gender - related differences in cognitive style, certain biological 10 factors and a higher incidence of psychosocial and economic stresses in women. Possible biologic mechanisms may include differences in brain structure and function, genetic factors and the cognitivebehavioral or mood-related effects of female gonadal steroids on neurotransmitters and enzyme functions in vulnerable persons. The objective of the study was to examine the difference in social origins of depression in men and women. 100 married women and 100 married men participated in the study.

Despite all the publicity, some are still not aware of depression as it is an actual illness. This may be because we use the terms 'depressed' and 'sad' interchangeably. It's normal to feel sad or 'depressed' now and again. But clinical depression is a medical condition, not just a passing mood, and has many physical and emotional symptoms that go along with it.

Sometimes, it takes a while for a person to realize they are depressed. The symptoms many creep up gradually and sometimes reach a certain level before a person realizes that something is wrong and, hopefully, seek for help. For some people, the stigma of depression prevents them from seeking help. Some people with mild depression did not even realize that they suffer from a medical condition.

Many people do not get detailed information on the causes, and early symptoms of depression. This is necessary because in public especially in rural areas are not properly understood regarding depression. Many parents or family members do not like to accept the facts of situation when the child or family member is depressed, they visit various care facilities, as well as religious places expecting a miraculous cure to such people.

The information regarding knowledge of rural women about the causes and early symptoms of depression dealt in this study shall be useful to equip them with factual knowledge, where as identifiable aspect taught to the women in rural areas is the grass root level to prevent occurrence.

\section{STATEMENT OF THE PROBLEM:}

A Study to assess the knowledge regarding effect and pilot indication of depression among rural women at selected village, Villupuram District.

\section{OBJECTIVE:}

1. To assess the existing level of knowledge regarding effect and pilot indication of depression among rural women.

2. To find out the association between the level of knowledge regarding effect and pilot indication of depression among rural women with their selected demographic variables.

\section{ASSUMPTION}

1. Women may not have some knowledge regarding effect and pilot indication of depression

2. Level of knowledge regarding depression difference from

3. Some demographic variable influence the level of knowledge among the village women regarding depression 
4. Rural women may not aware about the Mental Health Problems.

\section{METHODS AND MATERIAL}

Quantitative approach \& non experimental descriptive research design. 50 village women were selected by using Nonprobability Purposive sampling technique. The data was collected by Structured Knowledge Questionnaire regarding effect and pilot indication of depression. An interview schedule was used to collect the data.

\section{RESULT AND DISCUSSION}

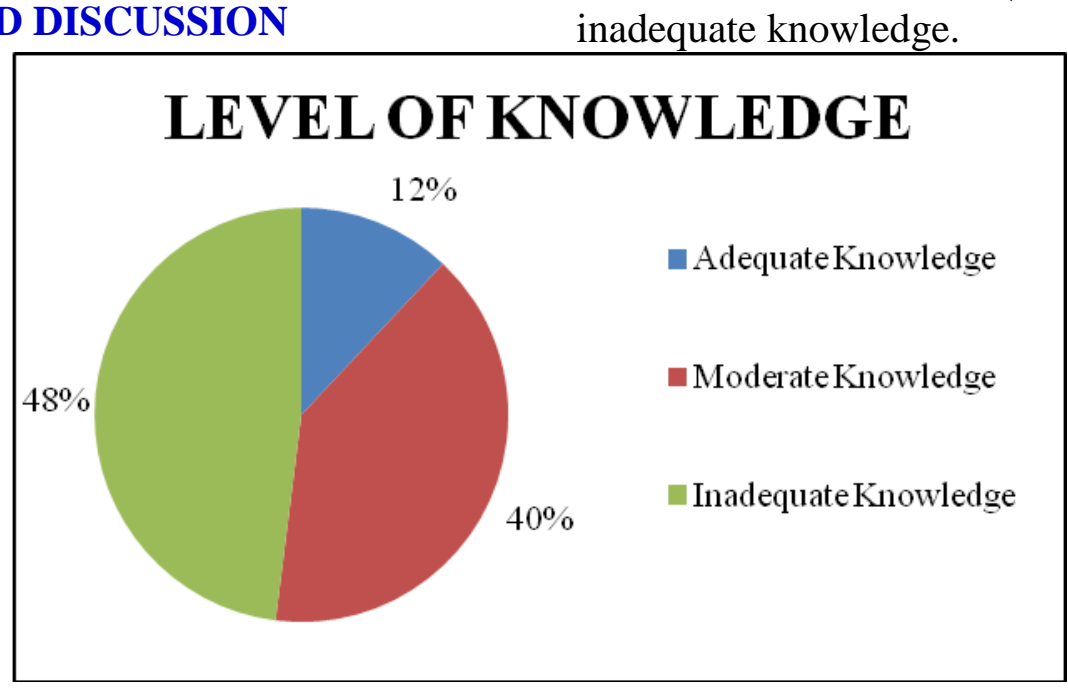

Associate between the level of knowledge among the rural women with their selected demographic variables.

Table 4.3: Association between the level of knowledge among the rural women with their selected demographic variables. $\mathbf{N}=\mathbf{5 0}$

\begin{tabular}{|c|c|c|c|c|c|c|}
\hline \multirow[b]{2}{*}{ S.No } & \multirow[b]{2}{*}{ Demographic Variables } & \multicolumn{3}{|c|}{ Level of Knowledge } & \multirow[b]{2}{*}{$X^{2}$ Value } & \multirow[b]{2}{*}{ P Value } \\
\hline & & Inadequate & Moderate & Adequate & & \\
\hline \multirow[t]{6}{*}{1} & \multicolumn{4}{|l|}{ Age in years } & \multirow[t]{6}{*}{5.94} & \multirow{6}{*}{$\begin{array}{l}0.65 \\
\text { NS }\end{array}$} \\
\hline & a. $35-40$ years & 3 & 3 & 1 & & \\
\hline & b. $41-45$ years & 8 & 9 & 2 & & \\
\hline & c. $46-50$ years & 6 & 6 & 1 & & \\
\hline & d. 51-55 years & 4 & 2 & 2 & & \\
\hline & e. 56-60 years & 3 & 0 & 0 & & \\
\hline \multirow[t]{6}{*}{2} & \multicolumn{4}{|l|}{ Educational status } & \multirow[t]{6}{*}{3.63} & \multirow{6}{*}{$\begin{array}{l}0.881 \\
\text { NS }\end{array}$} \\
\hline & a)primary education & 11 & 11 & 2 & & \\
\hline & b)secondary education & 7 & 5 & 2 & & \\
\hline & c)higher secondary & 2 & 1 & 0 & & \\
\hline & d)graduate & 1 & 0 & 0 & & \\
\hline & e) illiterate & 3 & 3 & 2 & & \\
\hline \multirow[t]{7}{*}{3} & \multicolumn{4}{|l|}{ Occupation } & \multirow[t]{7}{*}{4.26} & \multirow{7}{*}{$\begin{array}{l}0.93 \\
\text { NS }\end{array}$} \\
\hline & a) home maker & 13 & 7 & 3 & & \\
\hline & b) daily wages & 8 & 7 & 1 & & \\
\hline & c) farmer & 1 & 1 & 0 & & \\
\hline & d)private employee & 2 & 5 & 2 & & \\
\hline & e)government employee & 0 & 0 & 0 & & \\
\hline & f) self employee & 0 & 0 & 0 & & \\
\hline
\end{tabular}


Kumudhavlli D et.al. Assess the knowledge regarding effect and pilot indication of depression among rural women at selected village, Tamil Nadu.

\begin{tabular}{|c|c|c|c|c|c|c|}
\hline & \multirow{2}{*}{\multicolumn{4}{|c|}{ Table 4.3 Continued... }} & \multirow{6}{*}{8.35} & \multirow{6}{*}{$\begin{array}{l}0.21 \\
\text { NS }\end{array}$} \\
\hline \multirow[t]{5}{*}{4} & & & & & & \\
\hline & a) $<5001$ & 10 & 8 & 5 & & \\
\hline & b) $5001-10000$ & 10 & 12 & 1 & & \\
\hline & c) $10001-15000$ & 3 & 0 & 0 & & \\
\hline & d)15001-20000 & 1 & 0 & 0 & & \\
\hline \multirow[t]{5}{*}{5} & \multicolumn{4}{|l|}{ Religion } & \multirow[t]{5}{*}{2.15} & \multirow{5}{*}{$\begin{array}{l}0.9 \\
\text { NS }\end{array}$} \\
\hline & a) Hindu & 22 & 20 & 6 & & \\
\hline & b) Muslim & 1 & 0 & 0 & & \\
\hline & c) Christian & 1 & 0 & 0 & & \\
\hline & d) others & 0 & 0 & 0 & & \\
\hline \multirow[t]{5}{*}{6} & \multicolumn{4}{|l|}{ Marital status } & \multirow[t]{5}{*}{2.56} & \multirow{5}{*}{$\begin{array}{l}0.861 \\
\text { NS }\end{array}$} \\
\hline & a) unmarried & 1 & 0 & 0 & & \\
\hline & b)married & 20 & 19 & 6 & & \\
\hline & c)divorced & 0 & 0 & 0 & & \\
\hline & d) widow & 3 & 1 & 0 & & \\
\hline \multirow[t]{4}{*}{7} & \multicolumn{4}{|l|}{ Type of family } & \multirow[t]{4}{*}{15.76} & \multirow{4}{*}{$\begin{array}{l}0.033^{*} \\
\mathrm{~S}\end{array}$} \\
\hline & a) nuclear family & 20 & 20 & 4 & & \\
\hline & b)joint family & 4 & 0 & 2 & & \\
\hline & c)extended family & 0 & 0 & 0 & & \\
\hline \multirow[t]{3}{*}{8} & \multicolumn{4}{|c|}{ History of depression in family } & \multirow[t]{3}{*}{4.55} & \multirow{3}{*}{$\begin{array}{l}0.107 \\
\text { NS }\end{array}$} \\
\hline & a) yes & 10 & 3 & 3 & & \\
\hline & b) no & 14 & 17 & 3 & & \\
\hline \multirow[t]{5}{*}{9} & \multicolumn{4}{|l|}{ Medical illness } & \multirow[t]{5}{*}{19.55} & \multirow{5}{*}{$\begin{array}{l}0.021 \\
\mathrm{~S}\end{array}$} \\
\hline & a)diabetes mellitus & 2 & 3 & 2 & & \\
\hline & b) hypertension & 4 & 7 & 2 & & \\
\hline & c)bronchial asthma & 2 & 0 & 0 & & \\
\hline & d) others & 16 & 10 & 2 & & \\
\hline \multirow[t]{5}{*}{10} & Hobbies & & & & \multirow[t]{5}{*}{4.83} & \multirow{5}{*}{$\begin{array}{l}0.56 \\
\text { NS }\end{array}$} \\
\hline & a) watching TV & 20 & 12 & 4 & & \\
\hline & b)listening music & 4 & 6 & 2 & & \\
\hline & c)reading books & 0 & 2 & 0 & & \\
\hline & d) handcraft & 0 & 0 & 0 & & \\
\hline
\end{tabular}

The table 4.3 shows there is significant between type of family and medical illness at $\mathrm{p}<0.05$ and there no significant between age in years, educational status, occupation, income, religion, marital status, history of depression in the family and hobbies

\section{DISCUSSION}

First objective of the study to assess the existing level of knowledge regarding effect and pilot indication of depression among rural women

In level of knowledge regarding pilot indication and effects of depression among 50 sample $16(32 \%)$ were in adequate knowledge, $10(20 \%)$ were in moderately adequate knowledge level,24 (48\%) inadequate knowledge level. The Knowledge Score mean is 10.48 with Standard Deviation of 3.765

Second objective of the study is to assess the existing level of knowledge regarding effect and pilot indication of depression among rural women.

The study shows there is significant between type of family and medical illness at $p<0.05$ and there no significant between age in years, educational status, occupation, income, religion, marital status, history of depression in the family and hobbies.

\section{CONCLUSION}

Among 50 samples, $48 \%$ had inadequate knowledge regarding pilot indication and effect of depression, $40 \%$ had adequate knowledge regarding pilot indication and effects of depression and remaining $12 \%$ had adequate knowledge. The study conclude that most of women having inadequate knowledge regarding pilot indication and effects of depression.

Acknowledgement: None

Conflict of Interest: None 
Kumudhavlli D et.al. Assess the knowledge regarding effect and pilot indication of depression among rural women at selected village, Tamil Nadu.

\section{Source of Funding: None}

\section{BIBLIOGRAPHY}

1. Albert, P.R., 2015. Why is depression more prevalent in women? J. Psychiatry Neurosci. 40 , $219-221$. http://dx.doi.org/10.1503/jpn.150205

2. Arrieta, J., Aguerrebere, M., Raviola, G., Flores, H., Elliott, P., Espinosa, A., Reyes, A., Ortiz-Panozo, E., Rodriguez-Gutierrez, E.G., Mukherjee, J., Palazuelos, D., Franke, M.F., 2017. Validity and utility of the patient health questionnaire (PHQ)-2 and PHQ- 9 for screening and diagnosis of depression in rural chiapas, Mexico: a crosssectional study. J. Clin. Psychol. http://dx.doi.org/10.1002/jclp.22390.

3. BS Ali, MH Rahbar, S Naeem, AL Tareen, A Gul, L Samad Prevalence of and factors associated with anxiety and depression among women in a lower middle class semiurban community of Karachi, Pakistan Journal of Pakistan medical association 200252 (11), 513.

4. Dr.MarcoPiccinelli. Dealing separately with artefactual and genuine determinants of gender differences in depressive disorders. International journal of social psychiatry. 2010 June; 46(2):P.112-9.

5. Gail Wiscarz Stuart, Michele T.Laraia. Principles and practice of psychiatric nursing. 8th ed. Missouri: Mosby Publication; 2005.p.330-336
6. Sandeep Grover, AlakanandaDutt, and AjithAvasthi. Global burden of disease. Journal of social psychiatry and psychiatric epidemiology. 2011 may;38(6):P. 290-6.

7. Khana P, WohraAK, et al. prevalence and pattern of depression among women in rural area. Indian journal of psychiatry 2006; 49(6): 243- 252.

8. Melinda Smith.M.a,et al. Depression in women. helpguide.org. 2011 October; 35(6):P. 123-127.

9. Menka J, Udit N. Knowledge and Attitude of 851 Nursing Personnel toward Depression. Indian journal of nursing. 2015 May 5; 3(5): p. 38-42.

10. Neena B, Shruti S. Depression in women in Indian context. Indian journal of psychiatry. 2015 July; 57(2): p. 239-45.

11. Polit, Hungler BP. Nursing Researchprinciples and methods. 2001, 5th ed. Philadelphia (US): Lippincott Company;

12. PradapSharan. Anxiety and depression in women in India. Women's Health And Education Centre. 2009 Feb.

13. Ruth Beckmann Murrary. Psychiatric mental health care. 2nd ed. Missouri: Mosby Publication; 1983.p. 507-27.

How to cite this article: Kumudhavlli D, Karthi $\mathrm{R}$, M Porselvi et.al. Assess the knowledge regarding effect and pilot indication of depression among rural women at selected village, Tamil Nadu. International Journal of Research and Review. 2021; 8(4): 143-148. DOI: https://doi.org/10.52403/ijrr.20210420 